\title{
Konsep Ekonomi Pada Masa Ibnu Khaldun dan Al-Ghazali
}

\author{
Rezki Amalia Fathurrahman (90100118108) \\ Email:rezkiamalia56@gmail.com
}

\begin{abstract}
Abstrak
Konsep Ekonomi pada masa Ibnu Khaldun dan Al-Ghazali memiliki kesamaan konsep ekonomi Cuma yang membedakan dari Ibnu Khaldun dan Al-Ghazali adalah adanya konsep larangan menimbun uang, penghapusan riba dan jual beli uang yang merupakan konsep Al-Ghazali sedangkan Ibnu Khaldun tidak menjelaskan hal tersebut tetapi ada beberapa konsep yang sama dijelaskan antara Ibnu Khaldun dan Al-Ghazali yaitu, sama-sama menjelaskan konsep uang, evolusi pasar atau mekanisme pasar dan prakterk perdagangan antar wilayah atau perdagangan internasional. Jadi konsep yang dijelaskan oleh kedua tokoh tersebut adalah konsep uang yang dimana mereka berpendapat bahwa uang di gunakan sebagai standar harga atau standar pembayaran, sebagai media pertukaran, konsep evolusi pasar atau mekanisme pasar yang sama menjelaskan tentang mekanisme pasar berjalan secara alamiah sehingga tercipta antara hukum permintaan dan penawaran, praktek perdagangan antar wilayah atau perdagangan internasional yang mengatakan bahwa pendapatan akan meningkat jika melakukan ekspor impor suatu barang ke negara lain.
\end{abstract}

Kata Kunci: Konsep Uang, Mekanisme Pasar dan Perdagangan Internasional atau antar wilayah 


\section{Pendahuluan}

Konsep ekonomi Islam pada fase kedua memberikan perubahan pada ekonomi pada dinasti sebelumnya karena salah satu tokoh yang dimana konsep ekonominya relevan di masa sekarang ini. Salah satunya konsep ekonomi yang cukup terkenal adalah konsep ekonomi Ibnu Khaldun dan Al-Ghazali. Dimana konsep mereka ini sama-sama menjelaskan tentang konsep uang, evolusi pasar atau mekanisme pasar dan perdagangan antar wilayah. Cuma yang membedakan dari konsep mereka adalah Al-Ghazali membahas soal larangan menimbun barang, penghapusan riba, dan jual beli uang sedangkan Ibnu Khaldun tidak menjelaskan konsep tersebut. Selanjutnya Al-Ghazali menjelaskan konsep ekonomi Islam merupakan dasar dalam membangun perekonomian. Yang di mana Al-Ghazali mendefinisikan konsep fungsi kesejahteraan sosial dalam tiga tingkatan. Pertama kebutuhan dasar (daruriat) yang dimana kebutuhan ini manusia membutuhkan yang namanya makanan, pakaian dan tempat tinggal. Kedua, kebutuhan pelengkap (hajiyat) yang dimana kebutuhan manusia sebenarnya bukan sesuatu yang vital atau diperlukan tidak diperlukan tetapi dibutuhkan untuk menghilangkan hambatan dan kesukaran hidup contoh punya kendaraan seperti mobil atau motor untuk digunakan manusia untuk beraktivitas. Ketiga, kebutuhan akan kemewahan (tahsinyat) yang kebutuhannya ini lebih dari sekedar untuk melengkapi dan manusia cenderung ingin membeli barang mewah untuk menyenangkan hati misalnya ingin membeli mobil, atau pakaian mahal. Selanjutnya Ibnu Khaldun yang terkenal dengan bukunya yang berjudul Mukaddimah yang diman buku ini berisi tentang bagaimana 
teori produksi, teori nilai, teori uang, teori harga dan distribusi dan bagaimana siklus pasar atau mekanisme pasar.(Adiwarman Azwar Karim 2017) 


\section{Pembahasan}

Konsep ekonomi yang akan di bahas pertama konsep ekonomi pada masa Ibnu Khaldun yang menjelaskan tentang teori uang yang mengatakan bahwa dua logam yang digunakan sebagai alat pembayaran emas dan perak adalah ukuran nilai yang dimana logam ini diterima secara alamiah dan nilai uang tidak mengalami fluktasi (naik turun) seperti harga barang.(Adiwarman Azwar Karim 2017) adapun beliau dituliskan sebagai berikut.

"Demikian, Allah telah menjadikan dua logam sebagai alat transaksi pembayaran yaitu emas dan perak yang bisa bernilai dalam perekonomian. Keduanya bisa menjadi alat pembayaran atau simpanan bagi penduduk dunia atau bumi. Jika alat transaksi ini nantinya digunakan untuk beberapa waktu yang akan datang. Maka tujuan utama dari dua logam tersebut adalah sebagai peredaran harga-harga pasar, karena kedua logam ini terjauh dari pasar masa itu"(Choirul Huda 2013)

Jadi maksudnya di masa depan uang bukan lagi sebagai alat pembayaran tetapi bisa digunakan untuk perdagangkan atau masa depan emas dan logam digunakan sebagai satuan ukuran nilai maksudnya harganya bisa diganti dengan uang kertas sebagai alat pembayaran. Selain itu ada juga konsep harga menurut beliau bahwa harga terbentuk dari hasil hukum permintaan dan penawaran kecuali emas dan perak sebagai standar moneter atau pembayaran. Menurutnya semua barang-barang akan terkena fluktasi tergantung bagaimana mekanisme pasar misalnya bila suatu barang langka maka harga naik dan permintaan bertambah 
tetapi bila suatu barang berlimpah maka harga turun dan permintaan akan berkurang karena menurut orang-orang barang-barang gampang didapat dan banyak dijual di pasaran sehingga tidak perlu untuk menaikkan harga. Perdagangan antar wilayah atau internasional yang dimana beliau menguraikan perdagangan internasional bukan saja jumlah tenaga kerja banyak dan produksi banyak tetapi juga memiliki keterampilan khusus dalam melakukan produksi salah satunya adanya tenaga kerja yang memiliki SDM yang baik jika suatu kota memiliki tenaga kerja yang memiliki skill keterampilan baik maka akan menghasil produksi barang dengan kualitas baik sehingga bisa bersaing dengan negara lain sehingga pendapatan suatu negara bertambah ini menyebabkan terjadi hukum permintaan dan penawaran karena didukung dengan produk dengan kualitas yang baik.(Adiwarman Azwar Karim 2017).

Konsep ekonomi Al Ghazali yang dimana berjasa juga dalam pengembangan teori ekonomi yang sesuai dengan zaman sekarang. salah satunya konsepnya adalah evolusi pasar yang sudah menjadi hukum alam bahwa manusia berhasrat untuk memuaskan kebutuhan akan ekonomi. adapun pendapat beliau yang mengatakan sebagai berikut.

“Mungkin saja petani bisa hidup jika peralatan untuk bertani tidak ada. Sebaliknya pandai besi dan tukang kayu ini hidup ditempat lahan pertanian. Jadi petani membutuhkan seroang pandai besi dan tukang kayu dan mereka secara bergilir membutuhkan petani. Secara alami, masing-masing akan ingin untuk memenuhi kebutuhannya dengan memberikan sebagian miliknya 
ini untuk dipertukarkan. Dapat pula terjadi pada tukang kayu membutuhkan makanan dan menawarkan alat-alatnya tetapi petani tidak membutuhkan alat tersebut. Atau jika petani membutuhkan alat, berarti tukang kayu tidak membutuhkan makanan. Keadaan inilah yang menimbulkan masalah. Oleh karena itu secara alami orang akan terdorong untuk menyediakan tempat penyimpanan alat-alat di satu pihak dan tempat penyimpanan pertanian di pihak lain. Tempat inilah tempat bertemunya pembeli sesuai kebutuhan mereka sehingga terciptalah suatu pasar"(Sirajuddin 2016)

Jadi maksudnya diatas adalah terjadinya barter atau pertukaran barang yang ingin dibutuhkan dimana ada seorang petani menginginkan sebuah besi dan tukang kayu untuk membuat peralatan pertanian dimana masing-masing ingin memenuhi kebutuhannya maka secara alami mereka menukarkan barang yang ia bawa masingmasing.

Aktivitas produksi yang dimana dalam produksi perlu adanya kerjasama antara tenaga kerja dan pemilik modal dalam melakukan produksi suatu barang.(Moh. Faizal 2015) adapun menurut Al-Ghazali mengklasifikasikan menjadi tiga. Pertama, produksi barang-barang yang dibutuhkan masyarakat sebagai kewajiban sosial maksudnya manusia membutuhkan sesuatu yang penting demi kelangsungan hidup seperti makanan dan pakaian, hierarki produksi adalah pembagian aktivitas produksi seperti produksi primer industri dasar yang dibutuhkan manusia seperti makanan, tekstil untuk pakaian dan kontruksi atau alat untuk perumahan, aktivitas penyokong yang sifat tambahan untuk industri pabrik 
seperti industri baja dan pengembangan tambang dan sumber daya hutan, aktivitas komplementer sifat penting untuk industri seperti pengilingan dan pembakaran produk yang sudah tidak layak digunakan lagi. Terakhir tahapan produksi seperti meyiapkan bahan dan alat produksi, melakukan pembagian kerja atau spesialisasi sesuai keahlian masing-masing. Konsep ekonomi yang dijelaskan Al-Ghazali juga yaitu larangan riba karena riba atau tambahan termasuk dosa dan terjadinya eksploitasi ekonomi yang memunculkan ketidakadilan dalam transaksi termasuk melarang menjual uang seperti emas dan perak karena uang bukan komoditas (barang) tetapi uang digunakan sebagai alat transaksi dan terakhir larangan melakukan penimbunan barang karena itu merupakan bentuk kezaliman yang seharusnya barang itu diedarkan ketika terjadi kelangkaan barang.(Adiwarman Azwar Karim 2017) 


\section{Kesimpulan}

Bahwa konsep ekonomi Ibnu Khaldun dan Al-Ghazali memiliki kesamaan konsep yang dimana sama membahas konsep uang Cuma yang membedakan dari mereka adalah Al-Ghazali membahas bahwa uang sebagai standar harga barang maksudnya standar pembayaran sedangkan Ibnu Khaldun membahas bahwa uang bisa digunakan dengan kertas sebagai alat transaksi selama berpegang pada nilai emas dan perak maksudnya jumlah uang yang dicetak sesuai dengan emas yang disimpan. Sama-sama membahas mekanisme pasar sehingga terjadi hukum permintaan dan penawaran. Sama-sama membahas tentang perdagangan antar wilayah. Tetapi yang membedakan teori Al-Ghazali dan Ibnu Khaldun adalah AlGhazali membahas tentang larangan riba, larangan menimbun barang dan larangan jual beli uang karena menurut uang digunakan sebagai alat pembayaran dan harus diedarkan kepada yang lainnya. 


\section{DAFTAR PUSTAKA}

Adiwarman Azwar Karim. 2017. Sejarah Pemikiran Ekonomi Islam. 4th ed. Depok: Rajawali Pers.

Choirul Huda. 2013. "Pemikiran Ekonomi Bapak Ekonomi Islam; Ibnu Khaldun." Economica : Jurnal Ekonomi Islam 4(1):103-24.

Moh. Faizal. 2015. "Studi Pemikiran Imam Al-Ghazali Tentang Ekonomi Islam.” Islam Banking 1(1):49-57.

Sirajuddin. 2016. "Konsep Pemikiran Ekonomi Al-Ghazali." Laa Maisyir 3(1):4660. 